\title{
简论国有企业为什么一定要成功--探讨国有企业成功的意 义
}

\section{吴坤洋}

广州市房实建设工程监理有限公司

DOI:10.32629/ej.v2i5.249

\begin{abstract}
[摘 要] 国有企业熟识又普通的称号,大部分认知印象中是新中国建立后的产物,计划经济时代图腾等,但事实上经大量的研 究发现,国有经济织组一直存在于人类活动当中,有着五千年历史的中国也不例外。笔者尝试从历史、经济实例、战略高度、 社会资源、资本生产力等角度层面,综合还原国有企业的历史样貌、展示发展现状、未来目标定义, 从中探寻发现国有企业的 成功对国家、经济、人民的重要意义。
\end{abstract}

[关键词]国有企业; 国资企业; 国资管理; 国有资产

\section{引言}

政府机构以及关联的保障支撑系统（包括民众福利、国 防、经济活动等) 持续运转需要消耗大量资源。随着人类社 会从封建社会形态发展为现代社会形态, 国家以单纯地直接 吸纳有限资源而实现支撑运转的形式是难以持续的。除此, 还有发行国债, 但是国债利息, 最终是用税金承兄, 没有摆脱 税金闭环, 依然是从社会财富中以法律之名进行粗爆吸纳。 如何回避这种对社会财富、经济循环直接且残爆的屠宰呢? 能否采用钱生钱, 利生利, 的思路呢? 调用部分税金投资实 体产业, 国家通过利润分配实现财政来源扩充, 避免直接吸 纳税金不断的扩大, 减少屠宰财富, 补充经济下行时可收税 金收缩造成的财政缺口。如此一来, 国企资本出现了, 随着发 展状大, 国企的存在与我们包括政府、民众等在内的各方利 益已密不可分, 成为国家、民众、社会与经济之间重要的联 系与调节。

拥有五千年历史文明的中国曾经创造人类社会的很多 个第一, 最早实现封建制度并推行 “车同轨、书同文”、最早 科技四大发明等, 同样 “国企” 概念初型产生最早也在中国。 历史上春秋战国时期管仲推行 “盐铁官营”, 后世朝代仿效 推行, 逐步形成国家层面的重要运作模式。西汉时期 “王莽 改新---王田制、私属制等” 几乎实现了古代的计划经济, 宋、元时期国家贸易垄断; 明、清两朝海禁、闭关锁国以及 一口通商, 乃至经过两次鸦片战争的失败后以 “富国自强” 为口号的 “洋务运动”。基于封建皇权、落后思维的历史背 景与需求, 给予了 “盐铁官营”、“寓税于价” 肥沃的土壤, 使这种特殊 “税收” 无形于一般税收同时存在于现实, 当然 以封建皇权、儒家思想为基础的 “国企” 作用自然是服务于 皇权为任务、以剥削人民为本质, 与现代调节经济、资源、 战略的理论思想完全不能等同, 甚至完全背离。

由于计划经济时代的特点, 国家除关税外的一般税收没 有强制性、迫切性需求, 国家财政收入与民众福利均通过国 企实现, 军事、科技、文化等也同样以国企为介质, 国企几乎
完全等同于国家税收与支付现实形式。由于整合了优势资源, 国企为新中国经济、科技、民众生活等追赶欧美列强奠定坚 实的基础, 并创造新的成绩与众所周知的贡献, 避免了 “盐铁 官营”历史以来对人民的整体化剥削问题。

经过 40 年改革开放实践证明, 以市场经济模式发展国有 企业是正确的, 是创造性的! 为什么说以市场经济模式发展国 有企业是创造性的? 首先, 不同于古代为了皇权战争、统治需 要单纯、贪婪、奴役地屠宰社会财富, 最终导致社会财富干渴, 引发社会动荡, 现有国企的经营是以向市场提供产品、服务 为主要任务与目标, 其中包括平衡市场供求关系、稳定市场 总体价格水平、市场法规推广传导体等;

其次, 除个别与国防有关的领域外, 市场、社会、自然资 源遵从市场经济规律, 谁掌握技术、谁预测市场变化准确、谁 运用资金投入高效, 则谁为主导资源, 包括买方市场与卖方市 场、国有资本与民营资本、规模经济与孤体经济竞争;

计划经济时代由于一般税收系统的缺失, 国家政府的直 接操控包括市场、产业、企业在内的整个经济循环是必须的, 因为当时国企的收入等同于税收, 国企的成本等同于社会福 利支出, 特别是直接承担全民职工就业、医疗、住房、教育 等社会福利, 可以说财政税收只是形式化存在, 只有法律上 的地位, 但没有现实的迫切性。当然, 在从公私合营到计划经 济国企, 再从计划经济国企到市场经济国企, 其发展过程中 行政性干预是不可缺少的, 本质上国企资本来源于国家财政, 最终的源头是税金。

如何管理好国有企业发展所带的利益与矛盾, 关键在清 晰理解现代国企对国家经济格局的重要意义与长远目标。

竞争平衡、风险对冲: 传统对市场经济的理解, 市场是 自由化的, 竞争化的、风险化的, 但是从已知及已发生的世界 经济重大历史事件的经验中发现, 纯粹的市场规律并不能完 全解决所有的经济问题。资本主义市场经济形成于欧美国家, 是以私有企业为基本的经济, 天然地携带了追逐高额利润的 基因, 一切影响获取高额利润的障碍都无法阻挡其贪婪的胃 
口, 直至崩溃为止。经济崩溃时首当其冲的必然是底层人民 群众, 他们没有资本、力量抵抗经济大棒的重击, 只能任其宰 割, 特别是在近代世界历史中处于落后被动的部分国家族群, 也包括近代的中国, 根本的原因是政府执行力的缺失, 影响 力无法张显, 完全力不从心, 甚至包括政府本身也是被动挨 打。国家对经济实施影响力的方式有很多, 传统经济学上大 多推广使用金融手段, 货币手段, 汇率手段、税收手段等, 但 这些方法只是变相的经济大棒, 同样会对底层人民群众造成 直接负面影响。欧美国家的资本主义市场经济是以私有资本 有基础, 市场是完全私有的市场, 政府没有根本性的话语权, 当市场失出平衡、风险爆发时谁都没有力量阻止, 这是问题 的关键所在。实现平衡就不能只存在一边的砝码, 或让一边 的法码份量过大, 市场也一样, 让国家资本通过国企参与到 市场中, 分布到各个行业, 在法制平等的前提下与私有经济 竞争实现天平恒定平衡, 并利用法制特别是反垄断法律防控 寡头。成功在行业市场毅立的国企, 可以把市场利润、资本 保留在中国境内, 避免部分强势私有企业的自由资金流出, 特别是通过国际贸易、汇率体系等渠道流出境外造成国家经 济空心化, 同时国企的产品服务实现一定市场份额占有, 防 止大量生产、消费资料过度依赖国外进口, 当面对国内外经 济风险爆发时道理也是相同。

经济战略纵深、财富分散储存: 国企、国有股份都是国 家税金的投资, 当然作为投资并不一定会有利润, 甚至可能 亏损。每个经济行业领域都存在高速发展和低速增长期, 当 处于高速发展期各种资本都会大量涌入, 而当处于低速增长 期资本迅速退出或沉没, 特别是带着自私自利基因的私有资 本, 市场价格、产品服务质量水平将会出现大规模动荡, 对整 体经济、个人消费者都是不利、有害的。市场行业领域的大 规模动荡, 必定首先体验在政府税金的减收, 特别是部分经 济较弱势地区, 税金减收也必定会间接影响政府所承担的社 会福利、服务的兑现。当某行业私有资本退出, 国有企业就 可能起到支撑作用使市场继续运作，同时把政府税金减收的 负面影响降低, 行业实现软着陆。企业的存在, 特别是国企的 存在是政府未来税金保障, 也是社会福利的保障, 又或者说 国企的存在, 是国家未来财富的希望。企业的利润及资产增 长, 从微观看是企业增值, 从宏观看, 是整个国家的财产增值 了, 企业资产处于优质状况, 也意味着国家资产的优质化。

第二财税系统、大规模减税基础: 现代国企与私有企业
平等纳税, 这与计划经济时代国企, 古代 “盐铁官营” 有着本 质的区别。企业, 也是现代公司法制的表现, 企业需要向股东 从利润中分红的, 作国企也不例外, 在正常纳税以外, 同样需 要向股东--国家上缴利润。税金是向政府缴纳, 红利也是缴 纳给政府, 也就是部国企需要二次纳税--利润分配, 国家抽 取红利, 实际上是通过国有资产体系执行的第二财税系统。 由于存在第二财税系统, 国家政府对市场管控与财政收入, 拥有两个法定税收工具并灵活使用。中国是发展中国家, 改 革开放前 30 年高速增长后, 目前处于经济调整期, 经济、市场 处于转型阶段, 过去 10 年虽然经济保持增长但与前 30 年已不 可比, 这与经济规律、世界政治经济环境有关, 欧美国家经近 代两个世纪的高速发展后也同样遭遇这样的情况。要促进经 济就需要大规模减税, 但减税所造成的财政缺口如何补充? 这时候国企就起到支柱作用, 通过红利分配把税金缺口填补, 这与欧美国家选择削减调整国家福利实现促进经济的做法 不同的, 因为中国有国企, 欧美国家没有, 所以中国更有底气, 在不削减福利的同时推行大规模减税政策的原因。

对于私有企业, 他的成功很简单、粗爆: 赚钱, 或者说赚 高额, 甚至超高额利润, 不管任何情况下, 为赚取利润可以牺 牲除自身以外的一切, 包括国家与人民, 近代历史已有很多 实例证明, 特别是民国时期。那么对于国企呢? 既然是企业, 特别是现代企业, 国有企业当然也可以赚取利润, 甚至超高 额利润, 当然绝对不应该是垄断、非技术性、皇权化的爆利。

国有企业的成功表现在于在保障国家、人民长远利益目 标实现的过程中充分发挥其主柱作用。主柱保障作用包括社 会就业水平、第二财税、法律典范标杆、关键性基础科技、 生产服务资源供给、宏观经济平衡等。国企的成功, 意味着 国家、人民的成功, 国企的失败, 意味着国家、人民的失败, 因此, 国有企业不但要成功, 并且一定要成功!

\section{[参考文献]}

[1]国务院国资委.《国有资产评估管理办法》 [M].1991,11(7):196.

[2]全国人民代表大会常务委员会国务院反垄断局. 《反 垄断法》[M].2008,(8).

[3]德国思想家卡尔・海因里希 - 马克思.《资本论》 [M].1867,9(03):66-73.

[4]清朝康熙徐元文,张廷玉.《明史》[M].1867,9(02):57. [5]新中国国务院国家清史编纂委员会.《清史》 [M].2004,19(07):196. 